\title{
Shodhana of Vang by three different methods and its analytical study
}

\author{
Research article
}

\section{Ashwini Y Deshmukh ${ }^{1}$, Meenakshi D ${ }^{2}$, Amrutkar D², Paras D Golecha ${ }^{3 *}$}

1. Reader, 2. PhD Scholar, 3. P.G. Scholar,

Department of Rasshastra and Bhaishajya Kalpna, Y.M.T. Ayurved Medical College, Kharghar.

\begin{abstract}
The process of shodhana i.e. purification is designed for the alteration of the original properties of a substance. The concept of shodhana is being practiced in ayurvedic medicines since samhita kala. Term shodhana indicates the pharmaceutical process of purification of various metals and minerals which is essential before administering them into alchemical as well as therapeutic purpose, and this term is broadly used for Samskara. It was highly accepted by the Pioneers of Rasashastra (8th Century A.D.). Specifically for metals, to convert them into consumable, assimilable, body friendly, form it is important that their compact, hard structure be broken. Vang dhatu is grouped in putilohas and is extensively used in ayurvedic medicinal system for management of some critical diseases like prameha, klaibya etc. Shodhana and Marana are the basic procedures adopted for making these foreign and wild elements, body friendly and tamed to provide maximum benefit. There are a number of procedures explained in rasashatriya texts regarding Shodhana of vang dhatu. The Present paper is a sincere attempt to study physico chemical characteristics of vang dhatu purified by three different methods.
\end{abstract}

Keywords: Vang, Shodhana, Dhalana

\section{Introduction}

Therapeutic efficacy of the Ayurvedic drugs has been established and well documented by the great Acharyas in the form of classics attributed to them. However, lot of changes have occurred in our living milieu since the time these classics were written, Further the art of preparing the formulations requires certain amount of expertise and no information is available about the likely impact of changes in the manufacturing techniques. So it is need of the hour to study and well document, the effects of the different procedures carried out for obtaining the desired effects in pharmaceuticals preparations. One of the procedure explained is shodhana i.e. purification. The process of Shodhana is designed for the very alteration of the original properties of a substance. The concept of shodhana is being practiced in ayurvedic medicines since samhita kala. The ancient Ayurvedic Texts like Charaka Samhita have defined the concept of Shodhana. It says that Karana (Processing) is the refinement of the natural products which means imparting additional properties ${ }^{1}$. Term shodhana indicates the pharmaceutical process of purification of various metals and minerals which is essential before administering them into alchemical as well as therapeutic purpose, and this term is broadly used for Samskara ${ }^{2}$. The concept of Shodhana treatment was highly accepted by the Pioneers of Rasashastra (8th

*Corresponding Author:

Paras D Golecha

PG scholar,

Department of Rasshastra and Bhaishajya Kalpna,

Y.M.T. Ayurved Medical College, Kharghar

E-mail: dr.parasd.golecha@gmail.com
Century A.D.). If searched for the specificity of the nature of the substances to be put to use to and the shodhana processes adopted for them, it can be easily seen that the process has to be comparatively soft for softer substances. Specifically for metals, to convert them into consumable, assimilable, body friendly form, it is important that their compact, hard structure be broken. The first activity in the process of shodhana of metals is heating them to red hot or to melt. When the metal is melted or heated to red hot. The next activity in the process shodhana immediately involves nirvapa or dhalana ${ }^{3}$ i.e. quenching in liquids at room temperature, the whole of the crystal lattice or grain structure is deformed.

Vang dhatu is grouped in putilohas and is extensively used in ayurvedic medicinal system for management of some critical diseases like prameha, klaibya etc. Shodhana and Marana are the basic procedures adopted for making these foreign and wild elements, body friendly and tamed to provide maximum benefit. There are a number of procedures explained in rasashatriya texts regarding Shodhana of vang dhatu.

The Present paper is a sincere attempt to study physico chemical characteristics of vang dhatu purified by three different methods.

\section{Aim}

To conduct the analytical study of Vang after Shodhana by using three different methods.

\section{Objectives}

To study the concept of Shodhana.

To study the various methods of Shodhana of Vang in different texts. methods.

To perform Shodhana of Vang by three different 
To carry out analytical study of Vang after Shodhana by using three different methods.

\section{Material: \\ - Ashuddha vang \\ - Churnodaka \\ - Nirgundi swarasa \\ - Kumari swarasa \\ - Haridra churna \\ - Pithar yantra \\ - Palika Yantra \\ - Pair of tongs \\ - Gas burner}

Methods:

Three different methods of the shodhana (purification) were followed.

Method I - as per the reference in rastarangini; Small pieces of $100 \mathrm{~g}$ of vanga dhatu were prepared by using crushing method. Then the pieces of this metal were taken in a loha darvi (iron laddle). These pieces were melted by heating on low flame. The melted metal was immediately poured in a pitharyantra which was containing churnodaka. The sound heard during the process was noted. The purified cooled vanga dhatu after $1^{\text {st }}$ purification was obtained, washed with lukewarm water, dried and weighed. The same process was performed for another six times in different pitharyantras with fresh churnodaka ${ }^{4}$. The final sample of purified vanga (Sn) was subjected for XRF analysis.
Method II - As per the reference of rasatangini, the shodhana of the vang dhatu was carried out in kumari swarasa seven times ${ }^{5}$.

Method III - Preparation of haridrayukta nirgundi swaras: $30 \mathrm{~g}$ of haridra churna was mixed in $90 \mathrm{ml}$ of nirgundi swaras with constant stirring in SS vessel. This solution was divided into 3 equal parts and kept in 3 separate SS vessels for purification of vanga. The same procedure as mentioned above was carried out three times ${ }^{6}$.

\section{Observations and results: \\ Observations during the vanga (Sn) purification process}

All the procedures of vang shodhana of were carried out in the departmental laboratory of Y.M.T. Ayurvedic medical college, Kharghar, Navi Mumbai. Procedures were keenly observed and noted.

During the process of dhalan of liquefied vanga (Sn) into pitharyantra containing different liquid forms, a specific sound was noted. Initially it took 4-5 minutes for melting of vanga (Sn). The time taken for $2^{\text {nd }}$ and $3^{\text {rd }}$ step was comparatively more. Each time a greyish black coloured scum was formed over the surface while melting the vanga (Sn) on daarvi. Smoke was observed during successive heating. Vanga $(\mathrm{Sn})$ was collected at bottom of the pitharyantra with a big mass and some powder particles. On successive heating the vanga (Sn) in powder form was seen more and more. Along with shodhit vanga some black coloured particles were seen adhered to it which may be due to haridrayukta nirgundi swaras.

Table no.1: Physical changes/ variations in Vang after three types of Shodhana.

\begin{tabular}{|l|l|l|l|l|l|}
\hline & Weight & $\begin{array}{l}\text { Weight loss after } \\
\text { Shodhana(g) }\end{array}$ & Colour & Form & $\begin{array}{l}\text { Smell during } \\
\text { Dhalana }\end{array}$ \\
\hline Raw vang & $100 \mathrm{~g}$ & - & Bright silver & Foil & - \\
\hline In Churnodaka & $30 \mathrm{ml}$ & $8.6 \mathrm{ml}$ & Greyish silver & Pieces & - \\
\hline In Kumari swrasa & $30 \mathrm{ml}$ & $18.86 \mathrm{ml}$ & Silver & Mass & - \\
\hline $\begin{array}{l}\text { In Haridra yukta } \\
\text { Nirgundi swarasa }\end{array}$ & $10 \mathrm{~g}+30 \mathrm{ml}$ & $13.95 \mathrm{ml}$ & $\begin{array}{l}\text { Bright silver }+ \\
\text { yellow tinge }\end{array}$ & Coarse powder & Herb smell \\
\hline
\end{tabular}

The elemental analysis was done with the help of X-ray Fluorescence (XRF) analysis of the raw and purified samples was done at Varsha Bullion \& Elemental Analab, Mumbai-02. X-ray tube volume of 15/50kV and current was used between 200-500 $\mu \mathrm{A}$. MODEL NO.-Horiba machine, Mesa-500. The XRF method depends on principles involving interaction between electron beam and X-ray with samples. The analysis of major and trace elements in material by XRF is made possible by the behaviour of atoms when they interact with radiation.

Table no.2: Elemental analysis of Vang by XRF in Mass \% .

\begin{tabular}{|l|l|l|l|l|}
\hline Elements & Raw vang (\%) & $\begin{array}{l}\text { Churnodaka shodhit } \\
(\%)\end{array}$ & $\begin{array}{l}\text { Kumari Swarasa } \\
\text { shodhit (\%) }\end{array}$ & $\begin{array}{l}\text { Nirgundi } \\
\text { Haridra churna (\%) }\end{array}$ \\
\hline (Cu) Copper & 0.45 & 0.07 & 0.07 & 0.21 \\
\hline (Sn) Tin & 99.08 & 99.85 & 99.88 & 98.83 \\
\hline (Pb) Lead & 0.47 & - & - & 0.27 \\
\hline (Ca) Calcium & - & 0.08 & - & - \\
\hline
\end{tabular}

Discussion:

In the procedure of shodhana, the physical and chemical characteristics of raw vang changes at different stages. It is found that, after the shodhana procedure the reduction in weight of vang was minimum in churnodaka and maximum in kumari swarasa. i.e the weight loss was $\mathbf{8 . 6} \mathbf{~ g}$ and $\mathbf{1 8 . 8 6} \mathbf{g}$ respectively. After the shodhana of vang 
by three different method, hardness of all the shodhit samples was reduced. But it was significantly reduced in haridra churna yukt nirgundi swarasa. Shuddha vang was obtained in the form of coarse powder in this type of shodhana procedure. Lustre was reduced in significant manner in churnodaka shodhit vang only. Colour changes during and after shodhana were different and specific for every method as mentioned in table no. 1.

In the XRF elemental analysis of vang it was found that in the procedure of vang shodhan by churnodaka and kumari swarasa amount of Lead $(\mathrm{Pb})$ content was reduced to zero i.e. it was totally absent in shuddha vang. Whereas $0.47 \%$ lead $(\mathrm{Pb})$ was present in the Ashuddha vang. Also the net Tin (Sn) content was found increased in kumari swarasa shodhit vang i.e. $99.88 \%$.

\section{Conclusion:}

In the view of materials and methods used for shodhana and the results obtained from the organoleptic and chemical analysis, it can be concluded that the main objective of shodhana procedure i.e. purification of raw drug and removal of unwanted parts can be achieved. Shodhana is the initial and very important stage of bhasmikarana (incineration) procedure. Here it can be clearly seen that the process of shodhana of vang provides perfect base for the bhasma nirmana. The changes in hardness, colour and shape were very significant in above mentioned procedures. The weight loss of vang was minimum in churnodaka and maximum in kumari ,coarse powder form that is maximum reduction in hardness was obtained after shodhana in haridra yukta kumari swarasa which can help in bhasmikarana of vanga, and mainly the absence of Lead (Pb) in Kumari swarasa and churnodaka shodhit vang dhatu was significant. Maximum Tin (Sn) percentage $99.88 \%$ was obtained by Kumari swarasa shodhana. Here it can be stated that the purest quality of vang can be obtained in kumari swarasa shodhit vang as compared with Churnodaka and haridra churna yukta nirgundi swarasa shodhit vang.

\section{References:}

1. Vaidya Yadavaji Trikamaji Acharya, Charak samhita, viman sthan 8/87, Varanasi, Reprint-2009, Chaukhamba Surbharati Prakashan, chapter 4, shloka no.3.

2. Siddhinandan Mishra, Rasatarangini, Sharma S., $11^{\text {th }}$ ed. Hindi commentary 2004, 2/52.

3. Shastri Ambika Datta, Rasa Ratna Samuchchaya 8/43, Rasa Vagbhata, Chowkhamba Sanskrit Bhavan, 1st ed, 1988.

4. Siddhinandan Mishra, Rasatarangini 18/8-9, Sharma S., $11^{\text {th }}$ ed. Hindi commentary 2004.

5. Siddhinandan Mishra, Rasatarangini 18/14, Sharma S., $11^{\text {th }}$ ed. Hindi commentary 2004.

6. Siddhinandan Mishra, Rasatarangini 18/11-12, Sharma s., $11^{\text {th }}$ ed. Hindi commentary 2004.
Figure 1: Images of the Shodhana of Vang

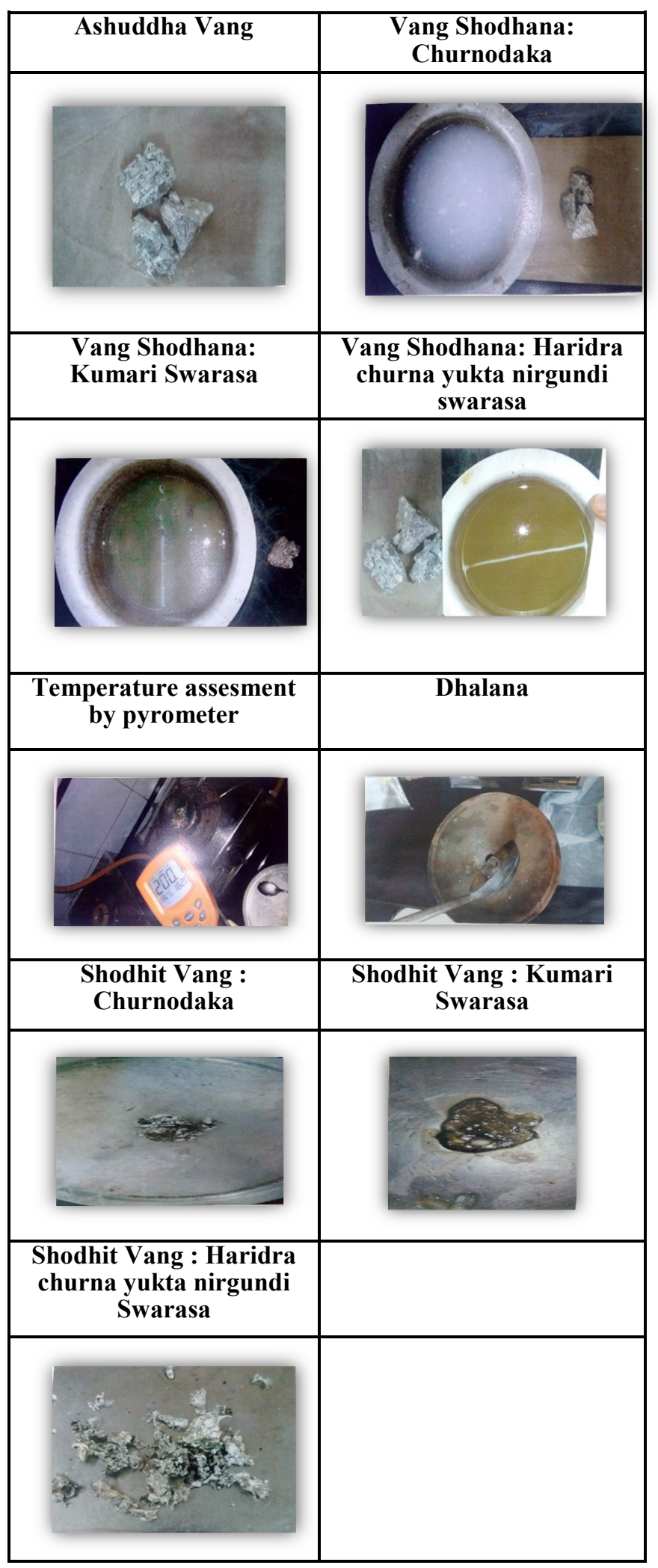

